\title{
Bediüzzaman Said Nursi’ye Göre Beşeri Yaşam Devirleri ve Malikiyet ve Serbestiyet Devri
}

$\ddot{O} z$

Vehbi KARA

İnsan ve toplum hayatı tarihsel süreç ve Bediüzzaman Said Nursi'nin eserlerinden yola çıkılarak incelenmiş kölelik sonrası dönemin «Malikiyet ve Serbestlik» isimli yeni bir dönem olacağı değerlendirilmiştir.

Toplumun yeterince özgürleşememe sebepleri, çalışma ve yönetim şekilleri üzerinde durularak ele alınmış insanların bu olumsuz şartlardan kurtulabilmesinin yolları araştırılmiştır.

Gelişim süreci içinde insanlığın başına gelen kölelik, esaret ve insan emeğinin sömürülmesi gibi olumsuz şartların bir gün mutlaka ortadan kalkacağı öngörülmüş gelmesi düşünülen bu devrin "Malikiyet ve Serbestiyet Devri" olması gerektiği izah edilmeye çalışılmıştır.

İnsanın yaşam serüveninde ortaya çıkan dönemler birbirinden farklı sosyal yaşam biçimleri ile üç bölümde ele alınmıştır. Bunlar Kölelik Öncesi Dönem, Kölelik ve Sömürü Dönemi, Kölelik Sonrası Dönemdir.

İnsanın yaşadığı bu devirler incelenerek toplumsal formasyonun en gelişmiş düzeyi olarak Kölelik Sonrası Dönem, diğer bir deyişle "Malikiyet ve Serbestlik Devri”" ileri sürülmüştür. Mülkiyet haklarının önem kazandığı ve her konuda tam bir özgürlüğün yaşanacağı bu dönemde mülkiyet, sahip olma ve hürriyet kavramları üzerinde yoğunlaşılarak özgün bir bakış açısı geliştirmeye çalışılmıştır.

Hürriyet ve özgürlük kavramlarının insanın çalışma hayatına ve sosyal yapısına olan etkileri incelendikten sonra çalışmanın diğer önemli bir konusu da "Kayıtdışılık" olarak ele alınmış bunun ülkelere yüklediği maliyetler göz önüne alınarak mülkiyet sisteminin önemi vurgulanmıştır. Bu sayede gelecekte daha fazla önem kazanacağı düşünülen mülkiyet ile ilgili kavramların yanı sıra yeni bir dönemin ana parametreleri tespit edilmiştir.

Anahtar Kelimeler: Kölelik, Malikiyet, Serbestiyet, Kayıtdışılık

\section{Eras of Human Living According to Bediuzzaman Said Nursi, and the Ownership and Liberty Era}

\section{Abstract}

In this paper, a new era named Ownership and Liberty has been drawn into focus. Emphasizing on the types of governments that impede freedom, questions are raised with respect to how people will be able to overcome these adverse conditions.

A discussion has been made on the question concerning the possible alleviation of negative conditions people faced (and are facing) through previous and present times such as slavery, thrall and the exploitation of human labor. It can be argued that Nursi sees the 
alleviation of these problems as part of an evolution process, and pointed out that the only way to succeed comprehensively would be via the reaching and attainment of the "Ownership and Liberty Era".

The different forms of social life are examined in three sections by emphasizing the eras which appeared in the adventure of human life through the lense of the Nursian framework. The first of these eras is named the "Primitive Communal Society" and Marx referred to it as the "Nomadic and Savagery Era". The second era is called the "Slavery and Colonial Era" and the third era is the "Ownership and Liberty Era". Slavery and the Colonial social order are studied in three sections, the first is basic slavery, the second is the thrall under the feudal order and the third is capitalism that is defined by its wage system.

Keywords: Evolution, Slavery, Ownership, Liberty.

\section{Giriș}

$\mathrm{Bu}$ çalışma ile tekâmül süreci içinde olan insanın yaşadığı devirler incelenmiştir. İnsanlığın kapitalizmden sonra geçireceği dönemin "Malikiyet ve Serbestlik Devri" olduğu doktora tezi ile ortaya konulmuş ve bu tez İstanbul Üniversitesi Sosyal Bilimler Enstitüsünde oybirliği ile kabul görmüştür.

Mülkiyet haklarının önem kazandığı ve her konuda tam bir özgürlüğün yaşanacağ 1 bu dönemde mülkiyet, sahip olma ve hürriyet kavramları üzerinde yoğunlaşılarak farklı ve özgün bir bakış açısı geliştirmeye çalışılmıştır.

\section{Beşeri Yaşam Devirleri}

Geçmişin bilgisi, günümüz toplumlarına ilişkin bir bakış açısı sağlar. Tarih, insanların sorunları nasıl belirlediklerini ve bunları nasıl çözmeye çalıştıklarını, bunun yanı sıra insan deneyimlerinin ortak yanını gösterir.

Tarihin incelemesi aynı zamanda değişimin incelenmesidir. Bu inceleme ve araştırmalar, değişimlerin niçin ortaya çıktığını ve etkilerini açıklamaya çalışırlar. Tarih, günümüze kadar geçmişte cereyan etmiş tüm olayların, bütün boyutları ile irdelenmesi, soruşturulması ve değerlendirilmesidir. Tarih; esas olarak değişim halindeki insan topluluğunun incelenmesidir ${ }^{1}$.

Uygarlık sözcüğü, Osmanlıca ve Arapçada "medeniyet” teriminin karşılığıdır. Uygarlığın kökeni kentleşme olduğundan medeniyet sözcüğünün kökü de "kent" ve "şehir" anlamına gelen "Medine" den kaynaklanmaktadır.

Uygarlık kelimesinin Avrupa dillerinde karşılığı olan "civilization” kelimesinin kökü ise Latince "civitas" yani kent kökünden gelmektedir. Uygarlıklar "çok gelişmiş kültürlerin sona ulaşmış aşamaları" olarak tanımlamıştır. Büyük ulus ya da imparatorlukların, başlangıç dönemindeki sosyal ve düşünsel tarzı "kültür" olarak nitelenmiştir. Bir kültür başlangıç aşamasını geçip kemikleşerek durgunlu-

1 Belma Tokuroğlu, Abdullah Ersoy, Uygarlık Tarihi, İmaj Kitabevi, Ankara, 2011, s. 1. 
ğa girdiğinde ise "uygarlık" olarak tanımlamıştır.

Bir kültür, yazıyı büyük ölçüde kullanmaya başlamış, bilim ve sanatta belirli ilerlemeler kaydetmiş, düzeni, güvenliği ve etkinliği sağlamak yönünde siyasi, sosyal ve ekonomik kurumlarını yeterince oluşturmuş ise bu kültürün uygarlık olarak tanımlaması mümkündür. Kısaca uygarlık, mağaralarda yaşayanların ya da ilk çiftçilerin yaşamlarına yön verenlerden daha karmaşık kuralları olan bir sosyal örgütlenme olarak tanımlanabilir.

Uygarlık, kent yaşamı, devlet, yazı, yasa ve matematik demektir. Bu olgular birbirine sık1 sıkıya bağlıdır. Kentte toplanan ve devleti kuran insanlar, toprağ 1 ölçmek, üretilen tahılı bölüşmek ve mevsimleri hesaplamak için matematiğe ihtiyaç duyarlar ${ }^{2}$.

Ayrıca başta mülkiyet konusu olmak üzere diğer alanlardaki yasaların topluluğun her yerinde yayılmasını sağlamak için yazıya ihtiyaçları vardır. Sulamaya dayalı tarım yolu ile artık ürünün merkezi bir elde toplanması gerekir. Böylece tarım ve zanaatkârlar arasında işbölümü ortaya çıkar. Bazı kişiler tarımdan ayrı olarak sadece zanaatla uğraşır.

Yine tarımla uğraşanlarla üretim yapmayan kâtipler, memurlar gibi devlet görevlileri arasında da bir işbölümü olmalıdır. İşte bu durum Mısır ve Mezopotamya bölgelerinde ortaya çıkmış köylerden toplanan ürün fazlası kent devletlerinin ambarlarında toplanmıştır.

\section{Sosyal Değişme - Sosyal Gelişme ve Egemenliğin EI Değiştirmesi}

Sosyal gelişmeler dikkate alındığında insanın şeref ve onuruna aykırı usul ve adetlerin, yavaş yavaş da olsa büyük ölçüde ortadan kaldırıldığı görülmektedir. Aynı şekilde kapitalist üretim yöntemleri ve katı kuralları olan kapitalizmin toplumsal yapısı da 1slah edilebilir.

Unutulmamalıdır ki kapitalist toplum, yapısı köleci toplumdan da feodal toplumdan da daha ileri ve daha insanidir. Zira köle esas itibariyle hem vücudu hem de hayatı mülkiyete konu bir eşyadır. Fakat kapitalist toplumda işçinin (proletarya) sadece emeği satın alınabilir. Fakat insan köle, esir olmak istemediği gibi ücretli olmak da istemez ${ }^{3}$. İnsanlık nasıl ki köle ve esir olmaktan büyük ölçüde kurtulmuştur. Ecirlikten de kurtulacaktır, kurtulmaktadır.

İnsanlığın ücretli sistemden kurtulma isteğini sosyal değişme modelleri ve tekâmül sürecini inceleyerek anlamak mümkündür.

2 Gordon Childe, Tarihte Neler Oldu, Çev. Mete Tunçay-Alaattin Şenel, İstanbul, Alan Yayıncıł lik, 1982, s. 12.

3 Bediüzzaman Said Nursi, Sözler, Zehra Yayıncılık, İstanbul, 2013, s. 635. 


\section{Sosyal Değişme Modelleri}

Sosyal değişme modellerinden de anlaşılacağı üzere birçok düşünce adamı ve yazar değişmeyi farklı yönleri ile ele almış her biri kendi nazariyesine göre değişim modelleri üretmiştir. Bu kadar farklı ele alış biçiminden elde edilecek en önemli sonuç, değişmenin mutlaklığ 1 ve ilerlemenin ekonomik, teknolojik ve bilimsel alanlarda bir kural teşkil edecek kadar yaygın olduğudur ${ }^{4}$

$\mathrm{Bu}$ modeller ele alınırken birçok konuda fikir birliğine varılan başlıkları bir önerme şeklinde sıralanmıştır ${ }^{5}$. Bunlar:

İnsanoğlunun evriminin belirleyici öğesi; teknolojidir.

İnsanoğlunun evrimi ahenkli ve tekdüze bir evrim değildir.

İnsanların bir toplumundaki değişme bütün insanları etkiler.

Her toplumsal yapı içinde mevcut durum taraftarları olduğu gibi değişimi isteyen öğeler vardır.

Toplumsal yapının bir öğesinin değişmesi bütün sosyal yapıyı etkiler.

Bir toplumdaki değişim, kısa vadede insanoğlunun genel evrim çizgisine uygun olmayabilir.

Fakat bir toplumdaki değişim, uzun vadede insanoğlunun genel evrim çizgisine ters düşemez.

\section{Evrim (Tekâmül) Süreci}

Aydınlanma geleneğinin özelliklerinden bir tanesi ilerlemedir. Siyasi ve toplumsal anlamda ilerlemeyi merkeze koyan bu düşünce tarzı, insanlığın her daim daha çok bilgiye ve mutluluğa erişebileceğine inanır.

Nursi'ye göre gelişme meyli vardır; onun ile evren, kanun-u tekâmüle tabidir. İnsan ise; âlemin semerat ve eczasından olduğundan, onda dahi meylü'l-istikmalden bir ilerleme meyli mevcuttur. Bu meyl ise telahuk-u efkârdan istimdat ile neşv-ü nema bulur 6 .

4 Ömer Faruk Uysal, http://omerfarukuysal.8m.com/kure001.htm 12.12.2014.

5 Emre Kongar, Toplumsal Değişme Kuramları ve Türkiye Gerçeği, İstanbul, Remzi Kitabevi, 1985, s. 112.

6 Bediüzzaman Said Nursi, Muhakemat, İstanbul, Sözler Yayınevi, 1977, s.13. 


\section{Çeşitli Kaynaklara Göre Beşeri Yaşam Devirleri}
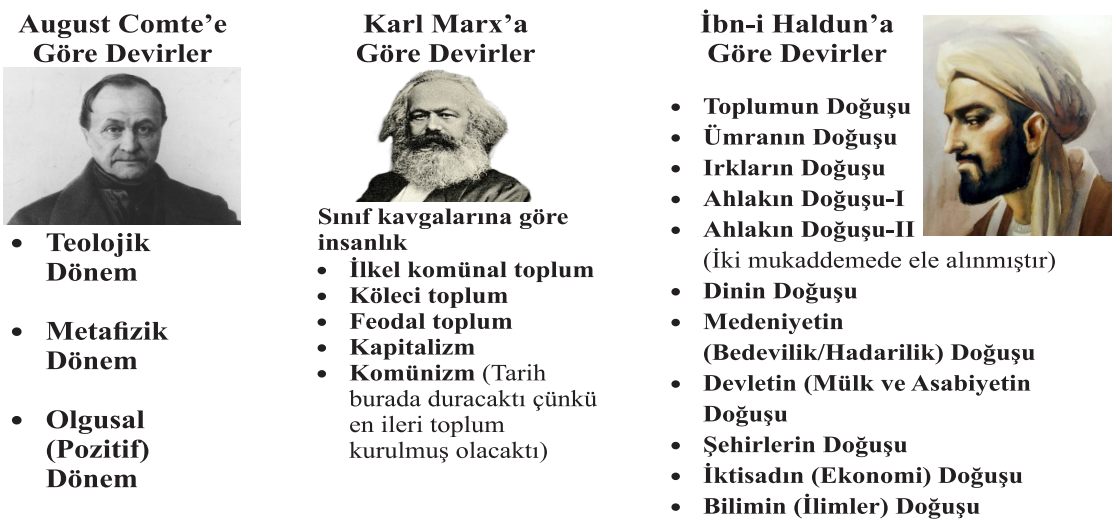

Toplumun maddi hayat şartları arasında toplumsal ilerlemeye egemen olan en etkin güç; üretim biçimidir. Toplumsal ilerlemeyi üretim biçimi adı verilen güç belirler. Üretim biçimi, temel olarak, insanların gereğini duydukları geçim araçlarının yani maddi servetlerin elde ediliş biçiminden başka bir şey değildir ${ }^{7}$. Beşeri yaşam devirlerini çeşitli biçimde ele alan düşünce insanlarına rastlanmıştır. Bunlardan bir kısmı Tablo 1'de gösterilmiştir.

Bu çalışmada Beşeri Yaşam Devirleri üç bölümde ele alınmıştır: Bunlar: Kölelik Öncesi Dönem, Kölelik ve Sömürü Dönemi, Kölelik Sonrası Dönem şeklinde sıralanmıştır. Kölelik ve Sömürü Dönemi de üç dönemde incelenmiş; İptidai Kölelik Devri, Esirlik Devri ve Ücretlilik Devri olarak incelenmiştir. Ücretlilik Devri de üç dönemde ișlenmiș; Vahși kapitalizm, Sosyalizm/Komünizm ve Modern kapitalizm (içinde bulunduğumuz dönem) şeklinde ele alınmıştır. Bu dönemleri Tablo 2'de şu şekilde görülebilir:

\begin{tabular}{|c|c|c|c|}
\hline Devirler & \multicolumn{3}{|c|}{ Dönemin Adı } \\
\hline 1. Aşama & \multicolumn{3}{|c|}{ Kölelik Öncesi Dönem } \\
\hline 2. Aşama & \multicolumn{3}{|c|}{ İptidai Kölelik Devri } \\
\hline 3. Aşama & \multirow{3}{*}{$\begin{array}{c}\text { Kölelik } \\
\text { ve } \\
\text { Sömürüi }\end{array}$} & \multicolumn{2}{|c|}{ Esirlik Devri } \\
\hline 4. Aşama & & \multirow{3}{*}{$\begin{array}{c}\text { Ücretlilik } \\
\text { Devri }\end{array}$} & Vahşi Kapitalizm \\
\hline 5. Aşama & & & Sosyalizm/Komünizm \\
\hline 6. Aşama & & & Modern kapitalizm \\
\hline 7. Aşama & \multicolumn{3}{|c|}{ Kölelik Sonrası Dönem (Malikiyet ve Serbestiyet Devri) } \\
\hline
\end{tabular}

Tablo 2: Beşeri Yaşam Devirleri

7 Georges Politzer, Felsefenin Temel İlkeleri, 5. bs. Çev. Erol Esençay, İzmir, İlya İzmir Yayınevi, 2010, s. 307. 
Nursi, kapitalizm sonrası bir ekonomik sistemden bahsetmiş Marx ile benzer önermelerde bulunmuştur. Bununla birlikte felsefi olarak farklı düşüncelere sahiptirler. Sosyal değişim modelleri ile ilgili olarak bu farklılık ve benzerliklerin ortaya konulması gereklidir. Bu konuda çatışma kuramının önemli temsilcilerinden olan Marx, çalışmalarını bütün insanlık tarihini ele alarak yapar.

Marx, tarihin ilk sınıf kuramcısı olup birçok yönüyle ilkleri ortaya çıkarmıştır. Tarihin son döneminde komünal hayatın tekrar ortaya çıkacağını iddia eden Marx, bir şekilde geriye dönüşü ve diyalektizmi ifade etmekle birlikte, üretim biçimlerine göre tarihi bölümlere ayırma metodu "Malikiyet ve Serbestiyet Devrinin" anlaşılmasına yardım etmektedir.

Gelecekte dünyanın nasıl şekilleneceğine dair düşünceler ileri sürmesi ve yeni bir dönemin ortaya konulması, tarihin dönemsel olarak ele alınmasında Marx'ın yöntem ve usulleri çok yararlı olmuştur.

Marx'a göre insanlığın tarihi, sınıf çatışması tarihidir. İlerleme ve değişim, çatışmalar sonucunda meydana gelmektedir ${ }^{8}$. Nursi'nin buradaki sınıflamasının diğer kuram ve yaklaşımlardan önemli bir farkı vardır. Auguste Comte'da pozitif aşamaya denk gelen sanayi toplumu, Nursi' de "ecirlik" devri olarak söylenmiş ve bu aşamada kalınamayacağı ifade edilmiştir.

\begin{tabular}{|c|c|c|c|c|}
\hline $\begin{array}{l}\text { BEŞERİ } \\
\text { YAŞAM } \\
\text { DEVIRLERİ }\end{array}$ & KARL MARX & $\begin{array}{l}\text { BEDİÜZZAMAN } \\
\text { SAIID NURSİ }\end{array}$ & \multicolumn{2}{|c|}{$\begin{array}{l}\text { BEŞERİ YAŞAM } \\
\text { DEVİRLERİ }\end{array}$} \\
\hline 1. Aşama & $\begin{array}{l}\text { İlkel Komünal } \\
\text { Toplum }\end{array}$ & $\begin{array}{c}\text { Vahşet ve } \\
\text { Bedeviyet Devri }\end{array}$ & \multicolumn{2}{|c|}{$\begin{array}{l}\text { Kölelik Öncesi Dönem } \\
\text { ( İlkel Komünal Toplum) }\end{array}$} \\
\hline 2. Aşama & Köleci Toplum & Memlukiyet Devri & \multirow{5}{*}{$\begin{array}{l}\text { Kölelik } \\
\text { ve Sömürü } \\
\text { Dönemi }\end{array}$} & $\begin{array}{c}\text { İptidai } \\
\text { Kölelik Devri } \\
\end{array}$ \\
\hline 3. Aşama & Feodal Toplum & Esirlik Devri & & Esirlik Devri \\
\hline 4. Aşama & Kapitalist Toplum & \multirow{3}{*}{ Ücretlilik Devri } & & \multirow{3}{*}{$\begin{array}{c}\text { Ücretlilik } \\
\text { Devri }\end{array}$} \\
\hline 5. Aşama & \multirow{3}{*}{$\begin{array}{l}\text { Sinıfsız Toplum } \\
\text { (Sosyalist/ } \\
\text { Komünist) }\end{array}$} & & & \\
\hline 6. Aşama & & & & \\
\hline 7. Aşama & & $\begin{array}{c}\text { Malikiyet ve } \\
\text { Serbestiyet Devri }\end{array}$ & \multicolumn{2}{|c|}{$\begin{array}{l}\text { Kölelik Sonrası Dönem } \\
\text { (Malikiyet ve Serbestlik } \\
\text { Devri) }\end{array}$} \\
\hline
\end{tabular}

Tablo 3: Marks -Nursi ve Beşeri Yaşam Devirleri

Ekonomi aynı zamanda bir ölçüm birimidir. Herhangi bir faktörün etkisini veya tüm etkisini belirlemek için bir bilgi yığınını makul bir şekilde değerlendirebilecek kuvvetli ve esnek bir dizi aracı kapsar.

8 Ayferi Göze, Siyasal Düşünceler ve Yönetimler, İstanbul, Beta Basım Yayım, 1986, s. 262. 
Toplumsal ilerleme ve gelişmeyi üretim biçimlerine göre ele almak ve üretim ilişkilerinde servetlerin elde ediliş biçimi göz önüne alınarak sınıflandırma gereği ortaya çıkmıştır.

\section{Kölelik Öncesi Dönem (İlkel Toplum-Vahşet ve Bedeviyet Devri)}

$\mathrm{Bu}$ devir insanlığın ilkel durumdaki ilk yaşama safhasını teşkil etmektedir. Her ferdin kendi başına yaşadığı, sosyal bir kontrol ve kaynaşmanın ve kamu otoritesinin görülmediği bir devirdir. Aile ve mülkiyet kavramları bu dönemde henüz gelişmemiştir. Toplum, dağınık ve basit bir yapı arz ediyordu. Bu devrin en önemli özelliklerinden bir tanesi toplumun emniyeti ve selameti için fert ve şahıslar kolaylıkla feda edilebilmektedir. Toplumun, klan veya kabilenin menfaati için şahısların hukuku nazara alınmaz. Bu devirde suç işlemiş bir tek insan yüzünden diğer kabile ve topluluğun tamamı öldürülüp yok edilebilmektedir.

Bu döneme "Vahşet ve Bedeviyet Devri" denilmesinin en önemli nedenlerinden bir tanesi fert hukukunun yok denecek kadar önemsiz kabul edilmesidir. Bu dönemde insanlar hayatlarını sürdürebilmek için gerekli olan şeyleri taştan yapılmış aletler aracılığı ile sağlıyorlardı. Sosyal üretim ilişkileri de, bu son derece ilkel üretim güçleri ile uyum halinde idi.

$\mathrm{Bu}$ dönemde iş araçlarının durumu insana tek başına ihtiyaçlarını karşılama imkânı vermiyordu. İlkel toplumun tüm üyelerinin güçlerini birleştirmeleri ile ancak gerekli olan şeyler sağlanabiliyordu.

İlkel komünal toplumlarda, devlet diye tanımlanabilecek kurumsal bir yapılanma söz konusu değildir ${ }^{9}$. Özel mülkiyet yerine ortak mülkiyet anlayışı tercih edildiği bu toplumsal yapıda, üretim araçları toplumun ortak malıdır. Bu durum insanların mülkiyet paylaşımında ve kendi eylemlerinin tanziminde yalnızca doğal hukuka bağlı oldukları ve sadece ona uygun düşündükleri bir özgürlük durumudur.

Doğa durumu aynı zamanda tüm otorite ve yargılama hakkının karşılıklı olarak herkese ait olduğu ve kimsenin kimse üzerinde herhangi bir egemenlik hakkının bulunmadığ 1 bir eşitlik durumudur. İş verimliliği son derece düşük olduğundan üretilen değerler insanların ancak yaşayabilmesi için zorunlu olanı sağlayabiliyordu. İhtiyaçtan fazlası üretilmediği için kimsenin bir artı değere el koyması söz konusu değildi. Sömürü olayı yoktu, bu sebeple de bir siyasi organizasyona ihtiyaç yoktu. Bu dönem; üretim güçlerinin gelişmesi, inanç ve siyasi klan, kabileler ile birlikte yavaş yavaş son bulmuştur.

\section{Kölelik ve Sömürü Dönemi}

Bu bölümde köleliği büyüme, duraklama ve çökme dönemleri gibi üç aşamada fakat farklı bir analiz yöntemi ile incelemek mümkündür.

9 Yildırım Torun, Demokrasi ve Cumhuriyet, Ankara, Orion Yayınevi, 2005, s. 14. 
Bir toplumda insanlara hukuken eşit muamele edilmesi, kardeşlik kavramlarının ekonomik adaletle tamamlanması gerekir. Çünkü ücretli insanların çoğunlukta olduğu kapitalist sistemde köle, halen "efendi" diyalektiğinin tutsağıdır. Sistem, kölenin simgesel düzeyde bir karşıll1k vermesini onu etkisizleştirerek yani karş111ğinda bir ücret ödeyerek engellemektedir ${ }^{10}$.

Klasik anlamda, kölelik ile ücretlilik esasına göre çalışma arasında temelde büyük bir farklılık bulunmamaktadır. Her ikisinde de insan, özgürlügünden taviz vererek başkasının işinde çalışmaktadır. Bu hali ile köleler-serfler-ücretliler arasında göreceli bir iyileşme olmakla birlikte bireysel özgürlük açısından çok büyük bir farklılık yoktur. Bu nedenle Köleci, feodal ve kapitalist toplum aynı başlık altında toplanmış "Kölelik ve Sömürü Düzeni” olarak ele alınmıştır.

\section{İptidai Kölelik (Memlukiyet) Dönemi}

Düşmanın itaat karşılığında hayatının bağışlanması her iki tarafa kısa vadede yararlar sağlar. Güçsüz taraf hayatta kalmakta, güçlü ise çok düşük bir maliyet karşılığında üretim gücünün artmasını sağlamaktadır ${ }^{11}$.

$\mathrm{Bu}$ devri karakterize eden köleler çoğunlukla savaş esiri idiler. Bunların köle halindeki yaşayışları, bir noktada isyanların doğmasına sebep olmuştur. Böylece, bu devrin insanı insanca yaşam hakkını elde etmenin mücadelesine başlamıştır.

$\mathrm{Bu}$ dönemde artık üretim araçları ferdi mülkiyete konu olduğu gibi üretici sınıf olan kölelerde mülkiyetin konusu idi. Üretim güçleri başkalarının ürettiği değerlere el konmasını sağlayacak ölçüde gelişmişti. Ancak bunun için köle işçilerin ürettikleri değerleri tüketmemeleri gerekiyordu. Kölelik yüzyıllardır yapılan çaba ve uğraşlara rağmen hala tamamen kaldırılamamıştır. Avustralya'da yapılan bir araştırmaya göre dünya genelinde 162 ülkede 30 milyon köle yaşamakta bunun sadece 14 milyonu Hindistan'da bulunmaktadir ${ }^{12}$.

\section{Esirlik Devri- Feodal Toplum}

Üretim araçlarının ortak mülkiyetten çıkıp özel mülkiyet halini alması ile birlikte, insanlar arasında eşitlik düşüncesi iyice tahrip olmuş, üretim araçlarını elinde tutan mülkiyet sahipleri ile mülkiyetten yoksun olanlardan müteşekkil eşitsizlikçi bir toplumsal yapı ortaya çıkmıştır ${ }^{13}$.

Kölelik adı verilen ve bu özelliklerle belirginleşen köleci Antik toplumun ardından aynı nitelikleri haiz ikinci bir toplumsal yapı yani feodal toplum ortaya çıkmıştır. Kölelerin sayısının azalması ve emek verimliliğinin düşük olması ne-

10 Jean Baudrillard, Simgesel Değiş Tokuş ve Ölüm, Çev. Oğuz Adanır, İstanbul, Boğaziçi Üniversitesi Yayınevi, 2001, s. 81-82.

11 Umut Omay, Emeğin Kültür ve Manipülasyon Teorisi, İstanbul, Beta Basım, 2009, s. 40.

12 Yasin Eskiköy, “Dünya'da 30 Milyon Modern Köle Var”, Sabah Gazetesi, 18.10.2013.

13 Torun, A.g.e. s. 15. 
deniyle üretim miktarının arttırılması için kölelere üretimden pay verilmesi düşünülmüş ve bu düşünce Roma'da fiilen gerçekleştirilmiştir. Köleler, tasarruflarına bırakılan küçük toprak parçalarına karşılık olarak, ürettikleri ürünün önemli bir bölümünü toprak sahiplerine vermek zorundadırlar. Ürün/rant biçimindeki bu yükümlülüklerinin yanında karşılıksız olarak toprak sahibinin özel toprağında da çalışmakla da (emek-rant) zorunlu tutulmuşlardır ${ }^{14}$.

Roma'nın parçalanmasından sonra yeryüzünde Doğu Roma (Bizans) ve benzeri yüzlerce devlet kuruldu. Bu devletler genellikle kendi kurucu milletlerinin ismi ile anılan devletlerdi. Düşmanlarını yendikten sonra sağ kalanlarını esir edip işlerinde çalıştırıyorlard1. 19. Yüzyıla kadar çoğunlukla bu ve benzeri yönetimlerle idare edildiler. Bu nedenle Feodal toplumda yaşayan insanlara "esir" ismi verilmiştir. Bu dönem kapalı aile ekonomisinin hüküm sürdüğü toprak ağalığı (feodalite) düzenidir.

\section{Ecir Devri- Kapitalist Toplum}

Feodalizmin yıkılmasının temel nedeni, işgücünün aşırı derecede sömürülmesiydi. Serf denilen bir çeşit esir statüsünde bulunan malikâne çalışanları, kitleler halinde bulundukları yerlerden ayrılmaya başlamışlardı. Kalanlar ise sistemin eski temel üzerinde sürdürülmesini sağlamak için sayıca çok azdılar ve yorgun düşmüşlerdi.

Ticaretin gelişmesi seyyar satıcılık sistemi denilen bir biçimle sınırlı olduğu sürece feodal toplumu daha az etkilemiş fakat yerleşik ticaret ve taşıma, aktarma merkezlerinin kurulması sonucunu vermeye başlayınca hız kazanmıştır.

Malikâne ekonomisinde görülenin çok üstünde bir uzmanlaşma ve işbölümünü içeren el zanaatları sadece kent nüfusunun kendi gereksinimlerini karşılamakla kalmamış; aynı zamanda kırsal nüfusun kent pazarlarında elde ettiği kazançlarla satın alabileceği malları da sağlamıştır.

Gemiciliğin, sömürgeciliğin, ticaretin, zanaatkârlığın gelişmesi sosyal yap1ların da altını üstüne getirmiş kapalı ekonomiden mübadele ekonomisine geçilmiștir. Genel yaşayıș seviyesi yükselmiș tüccarlar, zanaatkârlar, serbest meslek sahipleri ve aydınlardan meydana gelen bir orta sınıf meydana gelmiştir. Feodal üretim tarzı çözülmenin ileri bir aşamasına taşınmış, ticaret burjuvazisi zenginleşerek nüfuz sahibi olmuştur.

Ticaret ve sanayinin gelişmesi ile birlikte eskiden ticaret ve zanaatla uğraşan kentli orta sınıf artık sömürünün yeni merkezi olan işçi sınıfını ezmeye başlamıştır. Feodal toplumlarda görülen soylu-köylü sınıfı ayrımı, burjuva toplumunda yerini işveren-işçi sınıfi ayrımına bırakmıştır.

14 Paul Sweezy, Feodalizmden Kapitalizme Geçiş, 3bs. Çev. Müge Gürer- Semih Sökmen, İstanz bul Metis Yayınları, 1984, s. 37. 
$\mathrm{Bu}$ sistemde, sayıları az olan kapital sahipleri güçlerini gitgide arttırırken, sayıları her geçen gün artan işçi sınıfı daha da yoksullaşmaktadır. Geleceğin kapitalistleri olan bazı insanların elinde önemli boyutta sermaye birikirken, dolaysız üreticiler yani lonca zanaatçılarının önemli bir bölümü ve toprağını kaybedenler, üretim araçlarından koparak emeklerini ücret karşılığı sunmaya hazır geniş bir kitleyi meydana getirmişlerdir.

$\mathrm{Bu}$ dönemde artık manifaktürel üretim aşamasına ulaşılmıştı. Yeni tip girişimci, hammaddeyi kendi evinde işleyecek olan ustalara getiren (işveren aracılardan) farklı olarak daha ileri bir biçimde üretimi organize ediyordu.

Burada ücretli emekle birlikte sermaye bir araya gelmekte bir başka ifade ile kapitalizmin ilk çekirdeksel örgütlenmesi anlamına gelen fabrikasyon sisteminin doğuşu ortaya çıkmaktadır. Bu aşama eve iş verme sisteminden farklı olarak hammaddelerin yanında üretim araçlarının müteşebbislerce sağlandığı bir üretim örgütlenmesiydi.

Bundan sonra değişecek olan üretimin örgütlenme niteliği değil, üretim araçlarının muazzam gelişmesiydi. İşçiler işgüçlerini sürekli olarak yeniden satma özgürlüğüne sahipken, köleler bir defaya mahsus olmak üzere bir meta olarak köle sahiplerine satılmaktadırlar.

Kölelik-esirlik-ücretlilik dönemlerinin ortak özelliklerinden bir tanesi, insanların kendiişleri yerine başkasının adına çalıştırılması ve bir başka ifadeyle insan emeğinin sömürülmesidir. İçinde bulunduğumuz hatta sonlarını yaşadığımız dönemi "ecir" devri olarak ifade edenler olmuştur. Ücret devri fakat karşıllı̆̆ tam olmayan ücretin devri; bu devir kapitalizmdir ${ }^{15}$.

\section{Kölelik Sonrası Dönem (Malikiyet ve Serbestiyet Devri)}

Kapitalist sistem ve asıl olarak bu sistemin korunması gayretinde olan güçler, sömürü düzenini hafifletmekle birlikte yine de halk isyanlarına çare bulamamıştır. Demokrasi ve insan haklarının gelişmesine paralel olarak kapitalizm, gerileme ve sona erme sürecine girmiştir.

Ücretleri belirli bir standardın (asgari geçim endeksleri) üzerine çıkmasına rağmen çalışanlar özgürlüğün farklılığını ve güzelliğini anlamış egemen sınıflara karşı daima kendi lehlerine olacak şekilde güçlenmeye devam etmiştir.

Artık emek sömürüsü bir mekâna, katı kurallara bağlı değildir. Emek fabrika duvarlarını aşmıştır fakat sanıldığının aksine esnek koşullar emeği özgürleştirememiştir. İnsanlar yaratılışı ve duyguları itibarı ile birisinin yanında köle veya işçi olmak istememektedir. İnsan şeref ve onuru bu sömürüye açık çalışma şeklini kabul etmemektedir ${ }^{16}$.

15 Cemil Ertem, "Malikiyet ve Serbestiyet", Star Gazetesi, 20.03.2011.

16 Çetin Veysal, Savaşın Felsefesi, 2. bs. İstanbul, Etik yayınları, 2010, s. 279. 
Yeni dönemin ismi; «Malikiyet ve Serbestiyet Devri» olup bu dönemde bireyin öne çıtı̆̆g, bireysel özgürlüklerin kamusal bir güvence ile arttı̆̆1, burjuva demokrasisinin kısıtlı ve temsili bireysel ifade gücünü aştığı bir dönem ifade edilmektedir.

Öte yandan malikiyet kavramı ile bireysel özel mülkiyeti, modern kölelik adı verilen ücrete dayalı çalışma yerine ortaklaşmanın belirleyici olduğu bir iktisadi nizamdan söz edilmektedir. Piyasa ekonomisi ve bilgisi en geniş şekliyle ortaya çıkmış ve herkese aynı anda, kesintisiz ulaşmaktadır. Burada tekel ekonomisi yerine serbest rekabete dayalı serbest piyasa ekonomisi geçerlidir.

Uygarlık ve kültürün savaşa ve sömürüye yatkın olan geçmişinden kurtularak barışçıl ve insan haklarına dayalı bir geleceğe doğru uzanan çizgide yol aldığı tarihsel bir gerçekliktir.

Gelecek ise kölelik ve sömürünün olmadığg Malikiyet ve Serbestiyet Devri olabilir.

\section{Kapitalizm ve Mülkiyet Sistemi}

Ayn Rand, mülkiyet hakkının, tüm diğer haklar gibi bir faaliyette bulunma hakkı olduğunu ifade ederek bu hakkın bir nesneye sahip olma değil bu nesnenin üretilmesi veya kazanılması faaliyetiyle, bu faaliyetin sonuçlarına ilişkin bir hak olduğunu söylemektedir ${ }^{17}$.

Bu hak, bir insanın herhangi bir mülkiyet kazanacağına dair bir garanti değildir, fakat sadece bir mülkiyeti kazanması durumunda onun sahibi olacağı yönünde bir garantidir. "Bu hak, maddi değerleri kazanma, muhafaza etme, kullanma ve tasarruf haklarını kapsar" denilerek mülkiyet kavramına yüklenilen anlamı görmek mümkündür.

Mülkiyet haklarının belirlenmesi ve taşınmaz malların değerlemesinin yapılması sayesinde bir ülkenin toplumsal ve ekonomik kalkınması büyük ölçüde sağlanabilir. Taşınmaz mal mülkiyeti devlet güvencesi altına alınması sayesinde ise hızlı bir kalkınma gerçekleştirmek mümkün olabilmektedir.

Aydınlanma filozofları için kapitalizm, özel mülkiyeti ve bu kapsamda bireyi koruma altına aldığı için tarihin sonudur. Fakat kapitalizmin çelişkileri ve çevre başta olmak üzere insan hayatına verdiği zararlar o kadar çoktur ki demokrasi ve insan haklarının gelişimi ile beraber bu sistemin ayakta kalmasına neredeyse imkân bırakmamıştır. Bu nedenle mülkiyet sisteminin yaygınlaşması sonucunda ortaya çıkan iktisadi sisteme kapitalizm adının verilmesi güçtür. Bu yeni devrin başka bir adı olması gerekir ki bu dönemin "Malikiyet ve Serbestiyet Devri" olduğu bir çok düşünce sahibi tarafından iddia edilmiştir.

17 Ayn Rand, İnsan Hakları, Bencilliğin Erdemi, Çev. Nejdet Kandemir, İstanbul, Plato Film Yał yınları, 2008, s. 142. 
Batı demokrasisinde, değişik düşüncelerin varlığ̣ ve yaşama hakkı temel hak olarak kabul edilmektedir. İnsanların arzu ettiği mutluluğa ulaşabilmeleri için ekonomik büyüme ve kalkınmanın yanı sıra toplum bireylerinin kişisel potansiyellerini özgürce koruma ve geliştirme yeteneğini elde etmesi hatta bunları geliştirmesi fırsatlara adil bir biçimde erişmesi gereklidir. Sosyal hakların gelişmesi ile birlikte hukuk önünde eşitliğin sağlanması yolunda büyük ilerlemeler kaydedilmiş bireysel hak ve hürriyetler önem kazanmıştır.

Bireysel hak ve hürriyetlerin devlet, toplum ve diğer bireyler karşısında muhafaza edilmesinin en önemli güvencesi ise anayasa olmuştur. Anayasal haklar sayesinde serbestlik adı verilen özgür düşünce ve ortam demokrasi denilen yönetim biçimi ile daha güçlü bir şekilde ortaya çıkmaktadır.

Demokrasinin gelişmesi ile sosyal haklar ve bireycilik arasında çok yakın bir ilişki mevcuttur. Malikiyet ve Serbestiyet devrinin anlaşılabilmesi ve özellikle de serbestiyet kavramı anlaşılmalıdır. Sosyal hakların gelişimi ve bireyciliğin zaman içinde önem kazanması sayesinde bu devir kendisini daha güçlü bir şekilde hissettirecektir.

\section{Kapitalist Toplumun Çelişkileri}

Günümüzde sosyalizm ve komünizm uygulamalarının başarısızlığı karşısında "Serbest Pazar Ekonomisi” sloganlaştırılarak kapitalizm dogmalaştırılmış ve bununla birlikte birçok olumsuzluk göz ardı edilmiştir. Hâlbuki sosyalizm başarısızlığı, kapitalizmin tek seçenek olduğunu kanıtlamaz

Rekabetçi kapitalizm, kapitalizmin doğası gereği kapitalist toplumsal formasyonun yapıcısı oldu ama sürdürücüsü olamadı. İşte bu durum kapitalizmin en önemli sorunu ve çelişkisi olarak var oldu. Bu çelişkiler; kanun önünde eşitlik ilkelerinin ihlali ve kapitalist toplumun niteliğinden biri olan efendi-uşak ilişkisi bağlamında da ele alınabilir.

Emek ile kapitalizm arasında zıtlıklar ve çıkar çatışması vardır. Sanayi devrimi öncesinde insanları işe koşmak veya bir başka ifade ile sömürebilmek için fiziksel zorlama kullanılırken günümüzde ise manevi zorlama ön plana çıkmaktadır. İşte bu manevi zorlama süreci "manipülasyon" kavramı ile açıklanmakta ve kültür ile gerçekleştirilmektedir ${ }^{18}$.

Kapitalizmin kendisini dayandırdığg temel unsur üretimden tüketime doğru bir kayışı gerektirmiştir. Kapitalizm, karı bireyselleştirirken rizikoyu toplumsallaştırmayı başarmaya çalışmakta bu maksatla emeğin manipülasyonu ortaya çıkmaktadır. Manipülasyon emek üzerinde üretim ve tüketim amaçlı olmak üzere iki şekilde yapılmaktadır.

Kapitalizm tarihsel çıkışını üretimi arttırma esasına göre gerçekleştirmiş ol-

18 Omay A.g.e. s. 1. 
masına rağmen zaman içerisinde sadece üretim ile varlığını devam ettiremeyeceği anlaşılmış tüketimin de varlığını sürdürmek için vazgeçilmez bir şart olduğu ortaya çıkmıştır.

Temel üretim unsuru olan insana ilgi böylece temel tüketim unsuru olarak da kabul görmeye başlamıştır. Bu değişikliğin nedeni manipülasyon sürecinin tüketim esnasında daha verimli olduğunun anlaşılması iledir.

\section{Kapitalizm ve Çevre}

Kapitalizm, insanı ve doğayı sömürme esasına dayanan bir yapıya sahip olduğu için, insan ve doğa üzerinde tahribata neden olmaktadır. Kapitalizm ve bünyesindeki tekelci sermayenin doğa ve çevre ile ilişkileri dünyayı büyük bir felaketin eşiğine getirmiştir.

Günümüzde sık sık doğa yıkımının nasıl hazırlandığı, zararın boyutları, çevreye zararlı ürünlerin nasıl meydana getirildiği ve Üçüncü Dünya ülkelerinin adeta bir çöplük haline getirildiği çeşitli yazar ve kuruluşların birinci gündem maddesini oluşturmaktadır. Dünya bir taraftan bakımsız ve çöplük haline getirilirken öte yandan açlik ve sefalet yaygınlaşmaktadır. Ekonomik ve siyasal nedenlerden başka çevre gereksinimleri açısında da kapitalizm kendi sonunu hazırlamıştır ${ }^{19}$.

"Ne olursa olsun önce ve her zaman kazanç" düşüncesinin simgelendiği kapitalizm ile çevrebilim (ekoloji) birbirine aykırı düşen iki kavram haline gelmiştir. Kapitalist düzen, çevreyi düzeltme savı ile bir takım girişimlerde bulunurken bile başka her şey gibi doğaya "mal” gözüyle bakmaktadır.

Kapitalizmin sınırsız kazanç güdüsü sınırları olan çevre ile bağdaşmamaktadır. Dünya nüfusunun büyük çoğunluğunun sömürülmesi gibi büyümeye yardımc1 olacak çevre zenginliklerinin de sonuna dek kullanılması insanın tekâmül ve evriminde doğal ve normal karşılanması gereken bir davranış değildir.

Kapitalizmin bu olumsuz özelliklerine karşı en etkili çözüm; çevre dostu insan olma özelliğidir. İnsanlar kendi çocuklarına emanet ettiği dünyanın harap bir şekilde bırakılmasını istemezler. Bu özellikleri nedeniyle özgürlükçü bir yaklaşım ile sömürü ve çevre yağmalanmasına karşı insanların dünyayı kendi mülkü olarak görerek sahip çıkması beklenmektedir.

\section{Mülkiyet Sistemi ve Kayıtdışılık}

Marx’a göre insanlar arasındaki mücadele ve savaşın kaynağı, sahiplenme duygusu ve dolayısı ile de mülkiyet problemidir. Bu yüzden üretim araçları özel mülkiyetin olmadığı ilkel komünal dönem, eşitlik ve adalet ilkeleri çerçevesinden bakıldığında, ideal bir sistem olduğu ifade edilmektedir. Oysa olması gereken sadece eşitlik ilkeleri değil güçlü-güçsüz, yöneten-yönetilen, efendi-köle,

19 Türkkaya Ataöv, Kapitalist Emperyalizmin Çevre Soygunu, İstanbul, İleri Yayınları, 2009, s. 38. 
zengin-yoksul, zenci-beyaz vs. üreten mekanizmaların tabiatını ve onunla ilişkiyi sorgulamaktır.

Gelişmiş batı ülkeleri mülkiyet sisteminin hukuki altyapısını sağlam bir şekilde kurarak dünyanın geri kalan ülkelerindeki halklara karşı belirgin bir üstünlük kurmuştur. Avrupa ve ABD'nin dünya üzerindeki hâkimiyetini tesis eden önemli etkenlerden bir tanesi demokrasi ve liberalizmdir. Bununla birlikte gözden kaçan en önemli hususlardan bir tanesi ise mülkiyet sisteminin hukuki alt yapısının hazırlanarak başarılı bir şekilde uygulanmasıdır. Öyle ki demokrasinin gelişmesi kadar önemli olan bu konuyu çeşitli araştırmacılar gündeme taşımışlardır.

Üçüncü Dünya Ülkelerinde ve eski komünist ülkelerin şehirlerinde, müteşebbis adeta kum gibi çoktur. Bir Ortadoğu çarşısından geçip bir Latin Amerika kasabasında yürüyüş yaparken veya Moskova'da taksiye binerken bir şeyler satmaya çalışan binlerce insan vardır. Bu ülke insanları ayrıca yetenekli ve coşkuludurlar. Neredeyse sıfır denecek bir sermaye ile para kazanma işinde dünyanın hiçbir yerinde rastlanmaz. Modern teknolojiyi kavrama ve kullanmaya son derece ehil olan bu insanları, müteşebbis ruhu olmamakla suçlamak doğru değildir.

Fakat bu ülkeler ekonomik olarak gelişmemişlerdir. Kalkınmak için ne denli büyük bir şevk içinde bulunmuş olsalar dahi üretemedikleri en önemli şeylerden birisi, sermayedir. Gelişmiş ülkelerdeki ekonomik sistemin can damarı ise sermaye olup kalkınmanın temeli olarak değerlendirilmektedir ${ }^{20}$.

Asya, Afrika, Ortadoğu ve Latin Amerika'daki ülkelerde yapılan araştırmalarda kalkınmak için gerekli bütün varlıklara sahip olduğu görülmüştür. En fakir ülkelerde bile yoksul insanların dahi birikimleri mevcuttur. Öyle ki fakir ülkelerdeki bu birikimin değeri 1945 yılından günümüze kadar almış oldukları dış yardımların toplamının 40 katı olduğu tespit edilmiştir.

Fakat konutların ve tapulu olmayan araziler üzerinde inşa edilmiş şirketlerin yükümlülükleri yeterince tanımlanmamıştır. Sanayi kuruluşları finansör ve yatırımcıların gözetiminden uzak yerlere kurulmuştur. Bu mülkler, üzerindeki hakların yeterince belgelenmemiş olmasından dolayı kolaylıkla sermayeye dönüşememektedir.

İnsanların birbirlerini tanıyıp güvendikleri yerlerin dişında mülk satışı yapılamamaktadır. Keza kredi almak için ipotek yapılamamakta ve bir yatırıma karşı hisse olarak değerlendirilememektedir. Gelișmiş Batı ülkelerinde ise her parsel arazi, her bina, her bir makine ve teçhizat, mülkiyet belgesi ile tescil edilmiştir. Bu varlıklar ekonominin bütünü ile ilişkilendirilerek katma değer elde edilmektedir.

20 Hernando De Soto, The Mystery of Capital. Why Capitalizm Triumphs in the West and Everywhere Else, New York, Basic Books, 2000, s. 32. 
Malikiyet ve Serbestiyet Devrinin en önemli göstergesi; varlıkları, tapular ile temsil etmekle onları birer sermaye olarak görebilmektir. Bu sayede ilk bakışta "döküntü" olarak görünen birçok maddeden sermaye ortaya çıarmak mümkün olmakta ve güçlü kapitalist kurumlara muhtaç olmadan ekonomik kalkınma gerçekleştirilebilmektedir.

Sahiplenme duygusu yani malikiyetin kökeni muğlaktır ve anlaşılması güç bir yönü vardır. Fakat gelişmenin anahtar kavramlarından bir tanesidir. Bu duygu Batının gelişip güçlenmesinin en önemli nedenlerinden bir tanesidir. Diğer biri ise demokrasi ve liberalizm olup tezde kullanılan manası ile serbestiyettir.

Geleceği tasvir etmek için çeşitli kuramlar geliştirilmiş sahiplenme duygusu ve demokrasinin çok önemli olduğu iddia edilmiştir. Bu nedenle insanlığın gelecek devri isimlendirirken "Malikiyet ve Serbestlik Devri” benimsenmiştir.

Kayıtdışılığın sebepleri değişik ülkelerde çok zorlu ve güç şartlar arasında yıllar süren araştırılmış sonucunda ortaya çıkarılmıştır. Bunun için Peru'da küçük bir elbise dükkânı açılmıştır. Bu maksatla defalarca Lima'nın merkezine seyahat edilmesi gerekmişti. Günde 6 saat sadece bu ruhsat alma işlemleri için harcandı ve sonuç olarak tam 289 gün ve 1231 Amerikan dolar masraf yapıldı. Burada yapılan 1231 dolarlık masraf o günlerde yürürlükte olan asgari ücretin tam 31 katı idi. Ayrıca kamu arazisi üzerine bir ev inşa etmek için gerekli ruhsat 52 devlet dairesinde 207 adet idari işlem sonucunda ancak 6 Y11 11 Ayda alınabildi.

Filipinlerde yasal olarak bir ev alınabilmesi ve bu sürecin tamamlanabilmesi 13 ile 25 yıl arasında toplam 168 adımda mümkün olabilmektedir. Mısır'da bir arazinin tescil edilmesi için eğer bir tarım arazisi üzerinde yasal bir ev inşa etmek isteniyor ise bu sefer yapılacak iş 611- yıl boyunca devlet dairelerine gidip gelmeyi gerektirmektedir.

Haiti'de sıradan bir vatandaşın kamu arazisine yerleşebilmesinin yollarından bir tanesi araziyi hükümetten 5 yıllığına kiralamak ve sonra satın almaktır. Yapılan araştırmada yerel iş ortakları ile birlikte çalışılarak bu kiralama işlemi gerçekleştirilmek istenmiş bu işle ilgili olarak 2 yıl süresince 65 bürokratik işlemin yapılması gerekmiştir. Toprağın satın alınması için ise 12 yıl süren ve 111 bürokratik işlemin sonuca bağlanması gerekmiştir. Kısaca Haiti'de yasal yoldan toprak edinmek toplam 19 yıl sürmektedir. Fakat bu kadar eziyete rağmen ülkede yasallığın devamı garanti edilmez ${ }^{21}$.

Gelişmekte olan ülkeler ile fakir ulusların ekonomik sorunları aşmada karşı karşıya kaldıkları en önemli özellikleri şu şekildedir ${ }^{22}$ :

Bir vatandaşın sahip olduğu varlıkların neler olduğu bilinmez.

21 De Soto, A.g.e. s. 26.

22 A.e. s. 11. 
Kişilerin adresleri belirsizdir ve kolaylıkla doğrulanamaz.

Borçlular borçlarını ödememek için kolayca kendilerini gizleyebilir ve benzer çareleri bulabilir.

Kaynaklar kolayl1kla sermayeye dönüştürülemez.

Sahibi olunan varlıklar hisselere bölünemez.

Varlık tanımlarının belirli bir standardı yoktur, varlıklar birbirleri ile karşılaştırilıp mukayese edilemez.

Mülkiyet ile ilgili kurallar şehirden şehire hatta mahalleden mahalleye farklıl1klar gösterir.

ABD'de Yaşayan Silahlı Vatandaşlar (Kovboylar) ele alınarak 19. Yüzyılda ABD'nin durumuna göz gezdirecek olursak bugünün fakir ülkelerinin karşı karş1ya kalmış olduğu sorunlardan pek de farklı olmayan bir durumla karşılaşılacaktır.

Britanya'dan gelen göçmenler, akıl almaz derecede karışık ve aynı zamanda çelişkilerle dolu bir toprak edinme sistemi ile karşılaşmışlardı. Örneğin geniş bir arazi, hem İngiliz Kraliyet ailesi tarafından bağışlanmış birisine, hem bir Kızılderili kabilesinden satın alındığ 1 iddiasında olan birisine hem de bu toprağ 1 yasama meclisinden maaş yerine almayı kabul etmiş birisine ait olabiliyordu.

Her bir kişi bu toprağı bazen hiç görmemiş bile olabiliyordu. Hatta daha kötüsü bu topraklar insanlar daha o toprağa gitmeden y1llarca önce göçmenler tarafından parsellenmiş ekilip biçilmekte bile olabiliyordu. İşte tam bir "vahşi batı" klasiği, karşıda durmaktadır. Bu yıllarda ABD'de niçin herkesin beline tabanca taktığı şimdi daha iyi anlaşılabilir zira tam bir vahşi hayat söz konusu olmuştur.

Kendilerine ait olmayan topraklara yerleşen öncüler; toprağa değer kazandıran şeyin kendi emekleri olduğunu söylüyorlardı. Mülkiyeti tesis etmek için resmi tapu senetleri veya gelişigüzel çizilmiş sınırlar değil o bölgeyi işgal eden ve toprağ1 geliştirenlerin hakkı olduğu iddiasında idiler. Devlet ve federal hükümetler tabii ki bu durumu kabul etmiyor; subayların kontrolündeki askeri birlikleri göndererek çiftlikleri ve binaları yakıp yıkıyorlardı. Fakat o belgede ikamet eden insanlar askerler gittikten sonra binalarını yeniden inşa ettiler ve hayatlarını bu zor şartlar altında idame etmeye çalıştılar. İște 200 yıl önce ABD'de yaşanan bu olaylar fakir ülkelerin bugünkü temel sorunlarıdır.

Sanayi devrimi 18. Yüzyılın ikinci yarısında İngiltere'de doğmuş ve oradan batı Avrupa ülkelerine yayılmıştır. Çağdaş sanayi tekniği şaşırtıcı bir hızla gelişmiş ve bu geliş̧me büyük ve derin toplumsan değişmelere yol açmıştır. Hızlı bir kentleşme ile belirlenen yeni bir oluşum ortaya çıkmış o güne kadar insanlık tarihinin kaydetmediği bir göç hareketi başlamıştır. Endüstri bölgelerinde kentleşme ile kendini ortaya koyan büyük nüfus birikimleri görülmüştür.

Böylece toplumsal gelişme ve değişmeler neticesinde daha önce hiç bu kadar 
büyük ölçüye ulaşmamış geniş bir işçi sınıfı ortaya çıkmıştır. Kentlerin nüfusu hızla artmış erkek, kadın ve çocuk iş̧̧ileri zor, ağır ve yıpratıcı çalışma şartlarıyla karşı karşıya bırakmıştır. 1950 tarihinden sonra dünyanın birçok fakir ve gelişmemiş ülkesinde Avrupa'nın 1880'li yıllarda yaşamış olduğu sosyal ve ekonomik benzerlikleri hatırlatan karış1klıklarla dolu bir ekonomik devrim meydana geldi.

Tarımda makineleşmenin yoğunlaşması, kırsal alanda işgücüne olan talebi azalttı. Tıpta elde edilen gelişmeler ve halk sağlı̆̆ uygulamaları çocuk ölümlerini azalttı ve insanların ortalama yaşam sürelerini arttırdı. Bu gelişmeler sonrasında insanların büyük bir kısmı şehirlere akın etmeye başladı. Şehirlerin nüfusları hızla artmaya başladı.

Bugün sadece Çin ve Hindistan'da yüz milyonlarca insan metropollere göç etmiş durumdadır. Fakat yoğun göçler sonucunda halkın nerede ise üçte ikisi gecekondularda yaşamaya başlamışlardır. Kontrolsüz yapılaşma sonucunda kanalizasyon sistemleri çökmeye yüz tutmakta ve caddeler işportacıların işgali altına girmektedir. Büyük kentler adeta yaşanmaz bir hal almaktadır.

Batının ekonomik zaferi şu noktada düğümlenmektedir; mülkiyeti sermayeye dönüştürebilmişlerdir. Gelişmekte olan ülkelerde yaşayan yoksulların ellerinde bulunan, ancak yasal olarak sahip olamadıkları taşınmaz malların toplam değeri 9,3 trilyon doların üzerinde olduğu ileri sürülmektedir. İşte gelişen ekonomiler için işaret edilen çıkış yolu bu ölü sermayenin sisteme kazandırılmasıdır.

URBAN (KENTSEL ÖLÜ SERMAYE)

\begin{tabular}{|c|c|c|c|c|c|c|}
\hline & $\begin{array}{c}\text { Total } \\
\text { Populaton } \\
\text { (millions) }\end{array}$ & $\begin{array}{l}\text { Urban } \\
\text { Population } \\
\text { (\%) }\end{array}$ & $\begin{array}{l}\text { Urban } \\
\text { Population } \\
\text { (millions) }\end{array}$ & $\begin{array}{l}\text { Urban } \\
\text { Dwellings } \\
\text { (millions) }\end{array}$ & $\begin{array}{l}\text { Informal } \\
\text { Urban } \\
\text { Dwellings } \\
\text { (millions) }\end{array}$ & $\begin{array}{l}\text { Value of } \\
\text { Informal Urban } \\
\text { Dwellings } \\
\text { (trillion US\$) }\end{array}$ \\
\hline ASIA & 1,747 & $29 \%$ & 503 & 101 & 85 & 1.75 \\
\hline AFRICA & 525 & $32 \%$ & 167 & 33 & 28 & 0.58 \\
\hline MIDDLE EAST \& NORTH AFRICA & 371 & $57 \%$ & 211 & 42 & 36 & 0.74 \\
\hline SOUTH AMERICA & 329 & $78 \%$ & 256 & 51 & 44 & 0.89 \\
\hline MEXICO \& CENTRAL AMERICA AND & & & & & & \\
\hline $\begin{array}{l}\text { THE CARRIBEAN } \\
\text { China NIS and Eastern Europe }\end{array}$ & $\begin{array}{r}161 \\
1,611\end{array}$ & $\frac{64 \%}{38 \%}$ & $\frac{103}{619}$ & $\begin{array}{r}21 \\
124\end{array}$ & $\begin{array}{r}18 \\
105\end{array}$ & $\begin{array}{l}0.36 \\
2.16\end{array}$ \\
\hline SUBTOTAL & 4,743 & & 1,859 & 372 & 316 & 6.48 \\
\hline Other Developing Countries & 191 & $39 \%$ & 75 & 15 & 13 & 0.26 \\
\hline TOTAL & 4,934 & & 1,934 & 387 & 329 & 6.74 \\
\hline
\end{tabular}

\begin{tabular}{|c|c|c|c|c|c|c|}
\hline & \multicolumn{6}{|c|}{ RURAL } \\
\hline & $\begin{array}{c}\text { Rural Area } \\
\text { (thousand } \\
\text { ha) }\end{array}$ & $\begin{array}{l}\text { Urban } \\
\text { Population } \\
(\%)\end{array}$ & $\begin{array}{l}\text { Urban } \\
\text { Population } \\
\text { (millions) }\end{array}$ & $\begin{array}{l}\text { Urban } \\
\text { Dwellings } \\
\text { (millions) }\end{array}$ & $\begin{array}{l}\text { Informal } \\
\text { Urban } \\
\text { Dwellings } \\
\text { (millions) }\end{array}$ & $\begin{array}{l}\text { Value of } \\
\text { Informal Urban } \\
\text { Dwellings } \\
\text { (trillion US\$) }\end{array}$ \\
\hline ASIA & 489,586 & $44 \%$ & 215,164 & 147,798 & 67,365 & 0.59 \\
\hline AFRICA & 736,639 & $50 \%$ & 368,792 & 68,166 & 280,626 & 0.39 \\
\hline MIDDLE EAST \& NORTH AFRICA & 444,685 & $40 \%$ & 177,866 & 59,660 & 118,206 & 0.25 \\
\hline SOUTH AMERICA & 607,407 & $49 \%$ & 297,895 & 51,006 & 246,689 & 0.24 \\
\hline \multicolumn{7}{|l|}{ MEXICO \& CENTRAL AMERICA AND } \\
\hline THE CARRIBEAN & 134,541 & $53 \%$ & 71,025 & 20,813 & 50,212 & 0.09 \\
\hline China, NIS and Eastern Europe & $1,151,280$ & $47 \%$ & 540,142 & 168,721 & 351,421 & 0.80 \\
\hline SUBTOTAL & $3,566,118$ & & $1,670,884$ & 556,164 & $1,114,719$ & 2.36 \\
\hline Other Developing Countries & 359,926 & $47 \%$ & 169,165 & 56,308 & 112,857 & 0.24 \\
\hline \multirow[t]{2}{*}{ TOTAL } & $3,926,044$ & & $1,840,049$ & 612,472 & $1,227,576$ & 2.60 \\
\hline & & & \multicolumn{2}{|c|}{ TOTAL INFORMAL } & \multicolumn{2}{|c|}{ US\$ 9.34 trillion } \\
\hline
\end{tabular}

Tablo 4: Dünya Ölçeğinde Ölü Sermayenin Miktarı (1997) 
Kaynak: Hernando De Soto, The Mystery of Capital. Why Capitalizm Triumphs in the West and Everywhere Else, New York, Basic Books, 2000, s. 32

\section{Mülkiyet Sisteminin Etkileri ve Tașınmaz Mallardaki Değer Artışları}

Varlıkları, onları aktif sermayeye dönüştürmemize izin verecek duruma getiren süreci, şekilleri ve kuralları sağlayan resmi mülkiyet sistemidir. Resmi mülkiyet kayıtları ve tapular, herhangi bir varlık hakkında ekonomik olarak neyin anlamlı olduğuna dair müşterek anlayışımızı böyle temsil ederler.

Bir varlığın potansiyel değerini kavramlaştırabilmek için gerekli bütün enformasyonu toplar ve organize eder böylelikle de onu kontrol edilmesi mümkün hale getirirler. Marx, Das Capital isimli eserine "meta" ile başlar ve mal, para, sermaye, emek ve değer kavramlarına, bunların birbirleri ile olan ilişkisine ve dönüşümlerine yer verir.

İbn-i Haldun'a göre amel ve sa'y (çalışma) bütün iktisadi faaliyetin temelidir. Malın hiçbir kıymeti yoktur. Önemli olan o malı üretmek için harcanan emektir. Dolayısı ile malın fiyatı, mala harcanan emeğin karşılı̆̆ anlamına gelir. Önemli olan o malı üretmek için harcanan emektir; dolayısı ile malın fiyatı, mala harcanan emeğin karşılığı anlamına gelir.

İbni Haldun; daha fazla üretim, maksimum etkinlik, kazanç ve kayıplar bakımından eylemlerin sonuçlarını taşıyan kar peşindeki girişimciler yoluyla, ticaret ve uzmanlaşma sayesinde elde edilebileceğini söylemiştir. En iyi devlet hukuk ve düzeni korumak için en az bürokrasi ve en az paralı askeri olan, kamu faaliyetlerini finanse etmek için vatandaşlarından en az vergi toplayan devlettir. Bu nedenle Dünya Bankası, İbn-i Haldun'u "özelleştirmenin ilk savunucusu" olarak övmüştür ${ }^{23}$.

Resmi mülkiyet sisteminin en önemli işlevlerinden birisi olan kadastro, her ülkenin kendi gereksinim ve amaçlarına göre yönlendirdiği, içeriği de buna göre belirlenen bir kamu hizmetidir. Ülkelerin toplumsal ve ekonomik gelişmesine bağlı olarak içerik kazanmakta, toplumun ihtiyaçlarını karşılamak üzere uygulanmakta, toplumun yapısı ve ihtiyaçları geliştikçe kadastronun kapsamı ve içeriği de değişebilmektedir. Günümüze kadar bu değişim tek boyutluluktan çok boyutluluğa doğru bir evrimi göstermektedir.

23 Stephen Glain, Islam in Office, Newsweek International, 03.07.2006. 


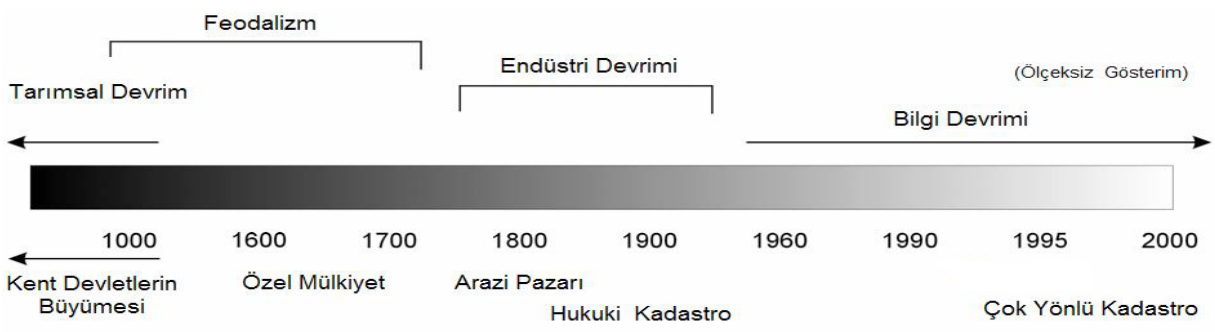

Tablo 5: Resmi Mülkiyet ve Kadastro Sisteminin Evrimi

Kaynak: Tülay Tufan, Hüseyin Erkan, S. Gökşin Seylam, Kadastronun Ekonomik Kalkınmadaki Rolü, Ankara, 13. Türkiye Harita Bilimsel ve Teknik Kurultay1, TMMOB Harita ve Kadastro Mühendisleri Odas1, 18-22 Nisan 2011.

Üzerinde zamanla daha çok insanın yaşama katılması, edinimi gittikçe güçleşen toprağın sürekli değer kazanmasına ve zenginlik kaynağı olmasına neden olmaktadır. Toprağın yanında, taşınmaz malların (konut ya da işyeri) değerleri de sürekli artmaya devam etmektedir.

$\mathrm{Bu}$ olgu, hemen hemen her ülkede güven içinde bir yatırım için, bugün olduğu gibi kredi kurumlarının kaynaklarını korkusuzca kullanmalarına ortam hazırlamaktadır. Batıda sermayeyi meydana getiren şey, resmi mülkiyet sistemlerinin karmaşıklığına gömülmüsş gizli bir süreçtir.

Batılı uluslar mülkiyet sistemini geliştirdikçe, farkına varmadan sermayeyi kolayca çıkartan farklı mekanizmalar geliştirmişlerdir. Bu mekanizmalar, bir varlığın ekonomik potansiyelini sermayeye dönüştürebilmemize olanak sağlayacak karmaşık mekanizmalar olarak değil de, sadece mülkiyeti koruyan sistemin parçaları olarak" algılanabilir. Bu konu ile ilgili olarak mülkiyet sistemleri etkileri altı başlıkta toplanabiliri ${ }^{24}$ :

Varlıkların Ekonomik Potansiyellerinin Belirlenmesi

Dağınık Enformasyonun Tek Bir Sistem İçerisinde Toplanması

İnsanlara Sorumluluk Verilmesi

Varlıklara Esneklik Kazandırılması

İnsanlar arasında A $\breve{g}$ Kurulması

İşlemlerin Kontrol Altına Alınması

\section{Malikiyet ve Serbestiyet Devri}

Özgürlük; bireyin başka insanların keyfi zorlaması altında olmaması, mülkiyet 24 De Soto, A.g.e. s. 47. 
ise özgürlük alanlarının teşhis edilebilmesinin, sınırlarının çizilebilmesinin ve korunmasının vazgeçilmez bir aracıdır. İnsanlığın "malikiyet" ile ecir yani ücretlilikten, "serbestiyet" ile esirlikten tamamen azat olup gerçek medeniyete kavuşacağ1 değerlendirilmektedir.

Gelecek bilimci Alvin Toffler, dünyada zenginlik ve refahın temellerinin zemin değiştirdiği üç büyük dönüşümden bahsetmektedir. Bu dönüşümler sırası ile avcılık ve toplayıc1lıktan yerleşik tarıma geçişi ifade eden birinci dalga, tarım toplumundan sanayi toplumuna geçişi ifade eden ikinci dalga ve sanayi toplumundan bilgi toplumuna dönüşümü ifade eden üçüncü dalga.

Üçüncü dalganın 1950'li y1llarda başladığını ve bilgi toplumuna geçişin temellerinin o yıllarda atıldığını ikna edici bir şekilde anlatan Toffler, içinde yaşadığımız ve başlangıcında olduğumuz yeni bir ekonomik ve sosyal çağın farkında olmakla birlikte adını bir türlü koyamamaktadır ${ }^{25}$. Toffler, "Future Shock" isimli eserinde gelecek korkusunu ele almış kapitalizmin bitmekte olduğunu ve yeni bir devrin başlamakta olduğunu ifade etmiştir ${ }^{26}$.

$\mathrm{Bu}$ sömürü ve köleliğin kaldırıldığı devrimci çağın bilgi toplumundan öte bir adı vardır; Malikiyet ve Serbestiyet Çağı.

Bütün insanlar için geçerliliğini koruyan temel ve doğal haklar, doğal hukuktan kaynaklanır. İnsanların var oluş itibariyle sahip oldukları ve kazanmak için insan olmaktan başka herhangi bir şartı gerektirmeyen temel ve doğal haklar;

Hayat

\section{Hürriyet}

Mülkiyet hakkıdır.

Yaşam hakkı tüm hakların kaynağıdır ve mülkiyet hakkı bu hakların pratiğe yansıyan şeklidir. Öyle ki mülkiyet hakkı olmaksızın hiçbir hak olamaz. Mülkiyet hakkı, özellikle İslamiyet dininin vermiş olduğu önemle birlikte bütün dünyaya yayılarak temel insan haklarından bir tanesi olduğunu göstermiştir.

Mülkiyet sisteminin gelişmesi ve tabana yayılması, ülkelerin hızlı bir şekilde sermaye üretmesine sebep olmuş refah seviyesinin artmasına ciddi bir katkıda bulunmuştur. Nursi, insanın doğasında olan bir duyguyu yani "sahiplenme, sahip olma" duygusunu ön plana çıkarmaktadır.

İnsanlar, başkalarının yanında çalışmak, emeğini sermayesi olan birisinin emrinde kullanmak yerine kendi işini kurmak, kendisine çalışmak istemesi doğal bir duygudur. İnsanların çoğu ücretli olarak başkasının yanında çalışmak yerine hiç olmaz ise başkası ile ortak olmayı tercih eder.

25 Arman Kırım, Türkiye Nasıl Zenginleşir? İstanbul, Remzi Kitabevi, 2008, s. 99.

26 Ömer Faruk Uysal, “Beşeri Yaşama Devirleri”, Köprü Dergisi, Kış 2000, s 49. 
İnsan, emeğinin karşıllı̆ını görmek hatta hata yapsa bile kendi hatası ile yaptı̆̆ 1 eylemin sonuçlarına katlanmayı kabul edebilir. Başkasının ve özellikle emeğini ücret karşılığında kullanan sermaye sahiplerinin yaptığı hatanın kendisine zarar vermesini kabullenmekte güçlük çeker. Malikiyet ve Serbestiyet Devri'ni çok genel olarak şu şekilde tarif etmek mümkündür:

Toplumun büyük kesiminin yani halkın, küçük dahi olsa mülk sahibi olması, kendi işini yönetmesi ve teşebbüs hürriyetini en geniş şekilde kullanmasıdır. Hürriyet ruhuna uygun olacak bir şekilde mal ve hizmet üretim, dağıtımında idarecilik fertlere veya gönüllülerce teşkil edilmiş gruplara bırakılmalıdır. Her ferdin satıcı ve alıcı olarak anlaşabilecekleri fiyattan alıp satmasına izin verilmelidir. Teşebbüs hürriyeti, özel mülkiyet ve piyasa mekanizması genel olarak kabul edilmelidir ${ }^{27}$.

Malikiyet kavramı, iktisadi anlamda malik olmak, üretmek, üretimine ve emeğine sahip olmak, onu özgürce değerlendirebilmek, tasarruf etmek anlamındadır. $\mathrm{Bu}$ kavram tekellerin ve tekelleri doğuran, koruyan ulus devletin de ekonomik olarak hâkimiyetini belirli bir ölçüde yitirdiği bir iktisadi nizam anlamına gelmektedir.

Siyasi anlamda; Hak ve hürriyetlerin olabildiğince genişleyip kitleler içinde faydalanılır hale gelmesi ve demokratikleşme olarak,

Hukuki anlamda; Kişilerin sözleşmeler yolu ile belirledikleri hukuki anlaşmaların önem kazanması ve geçerlilik kazanması, tahkim benzeri özel yargı organlarının devreye girmesi,

Kültürel anlamda; Çok kültürlülük, mahalli ve otantik kültürlerin önem kazanmas1, kültürlerarası etkileşimin artması olarak anlaşılabilir.

Adem-i merkeziyetçilik (üniter yapı yerine yerinden yönetim), katılım bankacılığ 1 (faizsiz bankacılık), işçilerin çalıştığı kurumlara ortak olmaları, anonim şirketlerin yaygın hale gelmesi, mülkiyetin halka (tabana) yayılması ve devre mülk sistemleri gibi günümüzde kısmen benimsenmiş ve kullanılmakta olan modellerinin daha gelişerek ortaya çıkması bu devrin özellikleri arasında yer alır.

Malikiyet ve Serbestiyet Dönemi'nin ikinci bir özelliği her türlü özgürlügün tarihin hiçbir döneminde olmadığ 1 kadar genişlemiş olmasıdır. Liberal demokrasinin meşruluğu üzerinde dünya çapında bir mutabakat oluşmuş ve aynı zamanda monarşi, faşizm ve komünizm gibi rakip egemenlik biçimleri karşısında galip gelmiştir. Halbuki, daha önceki hükümet biçimleri, kendi çöküşlerine yol açan büyük eksikliklere ve temel iç çelişkilere yol açmıştır.

Fakat serbestiyet ve bu dönemi ifade eden liberal demokrasi, özgürlük ve bağımsızlığa en gelişmiş bir şekli vermiştir. "İnsan haklarının açıklanışı gibi özgürlüğü, başkalarına zarar vermeyen her şeyi yapma hakkı olarak gören" dü27 Ömer Çapra, İslam Ekonomi Sistemi, İstanbul, Fikir Yayınları, 1970, s. 31. 
şünürlerin, geldiği son nokta liberal demokrasidir. Hâlbuki ne kendisine ne de başkasına zarar vermeyen her şeyi yapma hakkı gerçek özgürlüktür.

Bu noktadan da düşünüldüğünde kapitalizm sistemi ile malikiyet ve serbestiyet devri arasında ciddi ve derin ayrılıklar bulunmaktadır. Malikiyet ve Serbestiyet Devri yeni bir dönem ve insanlığın yeni bir devri olarak ele alınması gerekmektedir. Cemil Ertem "Ecir; yani ücret, emeğin tam anlamıyla erilmeyen karşılığıdır" diyerek içinde bulunduğumuz kapitalizm sistemini Bediüzzaman gibi "ecir" kavramıyla değerlendirmiştir. Bu nedenle kapitalizm ve kapitalizm sonrası dönemi inceleyebilmek için ücret ve ücret sistemlerini tarihsel açıdan ele alınması gereklidir.

Kapitalizmin feodalizmi ortadan kaldırması, toprağa bağlı köleliğe son vermiş olmakla beraber bu kez de; emeğin metalaştırılması süreciyle, ücrete bağlı bir çeşit kölelik şekli ortaya çıkmıştır. Kapitalist sistem, ücretli emek ilişkisinin ve özel mülkiyet hakkının sürekliliğinin ve genişlemesinin güvence altına alınmasını öncelikli olarak ele almıştır.

Bunakarşılıkinsan emeğinin sömürülmesi veözgürlüklerininkayıtlar altına alınmasına engel olamamıştır. Ücretliliğin köleliğinden sadece yarı zamanlı kurtulmak mümkün değildir: günde iki saat dahi olsa sömürülmek, yabancılaştırılmış bir çalışmaya mecbur olmak zamanın geri kalanında köleleşmektir.

Özgürlüğe kavuşturulmuş zaman ancak ve ancak eğer bu zamanın mantı̆̆ tüm veçhelerinde emek örgütlenmesine yayılmayı başarırsa özgür bir zaman haline gelir. Ücretli sistemin sona ermesi, herkesin kendisinin sevdiği işi yapması, insan hak ve hürriyetlerinin kâmil manada kullanılmasına imkân tanıyan malikiyet ve serbestiyet devrinde mümkün olabilir.

İnsanların kendi istidatlarına yani kabiliyetlerine uygun bir şekilde çalışması sağlandığı takdirde zorunlu çalışma diye bir şey olmayacaktır. Nasıl ki bir sanatkâr maddi kaygılardan ziyade kendi sanatını icra ediyor ise da benzer şekilde hoşlandığı işlerle meşgul olarak çalışabilecektir.

Diline, dinine, rrkına, cinsiyetine, milliyetine, sosyal statüsü ve rengine bakılmaksızın insana insan olduğu için tanınan haklara "insan hakları" adı verilmektedir. Avrupa İnsan hakları sözleşmesi ile kabul edilen "yaşama, işkenceye gayri insani muameleye veya cezaya tutulmama, zorla çalıştırılmama, adil ve tarafsız mahkemelerde makul bir sürede yargılanma, suçluluk ispat edilinceye kadar masum kalma, düşünce ifade ve din özgürlüğü" hakları günümüzde olduğu gibi gelecekte de insanların asla vazgeçemeyeceği haklardır.

Bütün bu haklar dünyada sosyal devlet, refah devleti ve liberal demokratik devlet anlayışının gelişmesine yol açmıştır. İnsanların kendi rızaları ve karşı1ıklı sözleşmeleri çerçevesinde oluşturdukları devletin asli amacı, insanların hayat hür- 
riyet ve mülkiyet gibi temel ve doğal hakların savunulmasını ve ülkenin yabanc1lardan gelebilecek tehlikelere karşı sağlamaktır.

Devletin kaynağı insanların tasvibini gerektirmekte bu durum da birey temelli bir siyasi organizasyonun kabul edilmesini gerektirmektedir. Birey temelli siyaset, diktatoryal rejimlere muhalif bir sistemin tecellisidir. Asli olan bireydir, devlet ise bireyler arasında düzeni sağlayacak vasıtadır. Locke tarafından temellendirilmeye çalışılan bu ideal devlet formu, liberal devlet ilkesi ile örtüşmektedir. Özellikle sosyalist olan bir toplumun aynı zamanda bireysel özgürlügü garanti etme anlamında demokratik olamayacağ 1 da iddia edilmiştir.

Bu bakımdan demokrasi halkın doğrudan veya dolaylı bir şekilde hükümranlığ ya da iktidar kullanımı olarak tanımlanabilir. Demokrasi monark veya belirli bir gruba dayanan egemenleri değil, halkı nihai olarak iktidar mekanizmasının yegâne kaynağ 1 şeklinde değerlendirilmektedir. Böylece demokrasi kavramı karş1lığını "halkın halk tarafından yönetilmesi" düşüncesinde bulur.

Buradaki yönetim kavramından kastedilen halkın siyasal kararları alması ve uygulamasıdır. Demokrasinin temel argümanları;

\section{Özgürlük}

İnsanların hukuk önünde eşit olmasıdır.

İnsanlar açısından özgürlük haktır ve gasp edilemez. Bir diğer varoluşsal hak olarak özel mülkiyet ise emek prensibi ile ilişkilidir. Kişinin emeği ile kazandığı mülkiyet üzerine herhangi bir insan tasarrufta bulunamaz.

Bu noktadan hareketle demokrasi, hükümet etme hakkını insani var oluşun ayniliği düşüncesine dayanan eşitlik ilkesi ve varoluşsal bir hak olarak özgürlük ilkesi ile ilişkilidir. Bu anlamı ile özgürlüğün ve eşitliğin hukuki düzeyde tanınıp güvence altına alındığı bir siyasal sistemdir.

Yeni bir mülkiyet dili inşa edilmesi gereklidir. Bu mülkiyet dilinin merkezine emeğin ve çalışmanın erdemi ile alın terinin onuru yerleştirilmelidir. Malikiyet ve Serbestiyet Devri, sadece ekonomik anlamda yașanması mümkün olan bir devir değildir. Siyasi, hukuki ve kültürel anlamda da karşılığı olan başı ıaşına ele alınması gereken bir dönemi ifade etmektedir.

\section{Sonuç}

Tarih, sosyoloji, iktisat ve siyaset bilimleri insanllğın çeşitli devirler geçirdiğini ve sosyolojik bir evrime tabi olduğunu ortaya koymuştur. İlkel komünal hayat$\tan$ (vahşet ve bedeviyet devrinden) köleleşmeye, daha sonra ise feodal ve kapitalist süreçlerden geçerek günümüze kadar geldiği ortak bir görüş haline gelmiştir.

Geleneksel toplum doğal hiyerarși düzeni üzerine kuruluydu. İnsanlar konumlarına göre farklı haklara sahiptiler. Geleneksel toplumda hiyerarşi kendini sak- 
lamazdı. Tersine hiyerarşinin simgelerinin sürekli gözler önüne serilmesine özen gösterilirdi. Bu simgeler hiyerarşiye toplum ötesi bir meşruiyet ve anlam verirdi.

Burjuva toplumuna geçiş yolunda, açık hiyerarşi üzerine kurulmuş bu toplum düzeni eleştirilmeye başlandı. Yeni hukuk, bireylerin özgür sermayeyle belirlenen hak ve yükümlülüklerini güvence altına alarak, içinde iktisadi ilişkilerin serpilip gelişebileceği, siyaset, ahlak ve tarihsel-toplumsal kalıtımdan özerk bir alan meydana getiriyor ve yine tahakküm üzerine kuruluyordu.

Ne var ki bu yeni tahakküm, doğal hiyerarşiden türeyen ayrıcalık haklarının tersine, kendini gizlemek zorundaydı. Çünkü yeni toplumsal tahayyül "insanın insan üzerine tahakkümüne" başkaldırmayla yoğrulmuştu.

Hukuk önünde eşitlik, insan haklarının temel ilkelerinden bir tanesidir. Efendi ile uşak arasındaki erdemsiz ve insan onuruna aykırı ilişki, bir gün mutlaka son bulmak zorundadır. Bu konuda sayısız çalışmalar yapılmış ve insan şeref ve onuruna uygun bir dönemin varlığı mümkün görülmüştür.

Malikiyet ve Serbestiyet Devri bu teorilerden bir tanesi olup insanca yaşam için gerekli şartları öne sürmektedir. Malikiyet ve serbestlik devrinin iktisadî açıdan önemli diğer bir özelliği; sermayenin belirli gruplar ve ülkeler elinde olmayıp daha geniş toplum kesimlerine hatta bireylerin eline geçmesine imkân tanıyan bir dönemi ifade etmesidir.

Sözleşme hukuku, mali piyasalar ve saygın tarafsız adli sistemle ilgili kurumların en önemlilerinden bir tanesi olduğu halde adından en az söz edileni "mülkiyet" haklarıdır. Eğer maliklerin mülkiyet hakları güven altında değil ise toprak, hisse senedi ve fikri hak sahiplerinin kendi mülkiyetlerinde bulunan alanlarda yatırım yapmaları veya gelişmelere ayak uydurmaları bir yük haline gelmektedir.

Eğer mülkiyet, otoritelerin denetimi ve düzenlemesi altında güvenilir bir biçimde alınıp satılamıyor ise piyasanın kendisi dinamik bir büyüme ve gelişme sağlayamayacaktır. Mülkiyet haklarının yokluğu insanların kayıtlı yani formel piyasadan kayıt dışı informel piyasaya doğru iten en önemli faktörlerden bir tanesi olmuştur.

Batı demokrasilerine bakıldığında güçlü hukuk sistemlerin yer aldığı ve mülkiyet haklarının korunduğu görülmektedir. Aslında bu ülkelerde dikkati çeken unsurlardan bir tanesi demokrasilerin mülkiyet haklarından istifade etmesidir.

Her birinde farklı toprak düzeni ve mülkiyet hakkı sistemleri mevcut olsa dahi bunların buluştukları ortak nokta; bireylerin mülkiyet haklarının korunması ve mülkiyetin mübadele edilebilmesi imkânının olmasıdır.

Herhangi bir malın ilk sahibinin kim olduğunu bilmek önemlidir ve bunu bilme hakkı her kişiye sağlanmaktadır. Bu mal satıldığında, kim alırsa veya kim 
teminat olarak kullanıyorsa kullansın bu işlemleri güvenli bir şekilde yapabilmek Bat1 demokrasilerinde kolaylıkla gerçekleşebilmektedir.

Gelişmekte olan ülkelerin birçoğunda mülkiyet hakları mevcut olmakla birlikte bu hakları tamamlayan hukuki çerçeve eksik kaldığından dolayı bu haklar ticaretin konusu olamamaktadır. Çünkü hukuki çerçeve, mülkiyetin, kullanımının en yüksek derecede değerlendirildiği ve büyük ölçüde güven altına alındığı alana doğru hareket etmesini sağlamaktadır.

Burada yapılması gereken işlerin başında özel mülkiyet haklarının korunması için hukuki yapılanmayı mümkün kılacak siyasi idrak ve anlayışa sahip olma yatmaktadır. Özel mülkiyet hakları, avcı toplumlarında dahi belli ölçüde var olmasına karşılık bugün hala birçok ülkede mevcut değildir.

Atılması gereken adımların ilk başında hangi mülkiyet haklarının var olduğunun keşfedilmesi ve buradan alınan sonuçlar ile Batı dünyasında kullanılan çeşitli modellerin gelişiminden edinilecek derslerle, bu mülkiyet haklarının hukuken korunabilmesi, en iyi şekilde örgütlenebilmesi için teşkilatlanmaya gidilmesidir. Batıdaki sistemlerin çoğu kendiliğinden oluşmuş bir süreç olmakla birlikte son 50-200 yıllık bir dönemde ortaya çıkmıştır. Çünkü Batı'nın Sanayi Devrimi'ni yaşadığ 1 yıllardaki iktisadi ve sosyal görünüm; karaborsanın, mafyanın, yaygın yoksulluğun ve hukuk tanımazlığın egemen olduğu bugünkü üçüncü dünya ülkelerine benzemekteydi.

Sahiplenme duygusu yani malikiyetin kökeni muğlak ve anlaşılması güç bir duygu olmasına rağmen gelişmenin anahtar kavramlarından bir tanesi olmuştur. Batının gelişip güçlenmesinin en önemli nedenlerinden bir tanesidir. Diğer biri ise demokrasi, liberalizm olup tezde geçen ismi ile serbestiyettir.

Geleceği tasvir ederken, çeşitli kuramlar geliştirirken sahiplenme duygusunun ve demokrasinin neden çok önemli olduğu, birçok araştırmacı tarafından kavramış ve izah edilmiştir. Bu nedenle insanlığın bu dönemdeki devri isimlendirirken "Malikiyet ve Serbestlik Devri" ismi kullanılmıştır.

Kalkınma sermaye gerektirmektedir; toplumlar bu gereksinimlerini, mülkiyetleri altındaki taşınmaz mallarını değerlendirerek sağlayabilme imkânlarına sahiptirler. Hak ve kısıtlamaların devlet güvencesi altında olduğu resmi mülkiyet sistemi veya diğer adı ile kadastro bu konuda önemli bir araç olarak ortaya çıkmaktadır.

İnsanların doğasında sahip olduğu maddeleri çok daha özenli ve gelecek kuşakların gereksinimlerini de dikkate alacak şekilde koruma ve kullanma duygusu vardır. Bunu gerçekleştirmek için devlet güvencesi ve emniyetin tesis edilmesi gerekmektedir.

Malikiyet ve Serbestiyet döneminin en önemli özelliklerinden bir tanesi mül- 
kiyet sistemi ve özgürlüklerin güvence altına alınmış olmasıdır. İnsanın tekâmülü, şeref ve onuruna uygun yaşama arzusu, bu taleplerinin her geçen gün daha da arttırmasına yol açmaktadır. Öylesine güçlü özgürlük akımları vardır ki en baskıcı devlet yönetimleri dahi bu gelişmelere karşı duramamaktadır.

Geri kalmış toplumların acilen yapması gereken işlerin başında bireylerin mülkiyet haklarının korunması gelmektedir. Zaten demokrasiler mülkiyet hakları sisteminin korunması ve varlıkların mübadele edilebilmesi hakkını güvence altına almıştır.

\section{Kaynakça}

Ataöv, Türkkaya: Kapitalist Emperyalizmin Çevre Soygunu, İstanbul, İleri Yayınlar1, 2009.

Baudrillard, Jean: Simgesel Değiş Tokuş ve Ölüm, Çev. Oğuz Adanır, İstanbul, Boğaziçi Üniversitesi Yayınevi, 2001.

Childe, Gordon: Tarihte Neler Oldu, Çev. Mete Tunçay-Alaattin Şenel, İstan» bul, Alan Yayıncilik, 1982.

Çapra, Ömer: İslam Ekonomi Sistemi, İstanbul, Fikir Yayınları, 1970.

De Soto, Hernando: The Mystery of Capital. Why Capitalizm Triumphs in the West and Everywhere Else, New York, Basic Books, 2000.

Ertem, Cemil: "Malikiyet ve Serbestiyet", Star Gazetesi, 20.03.2011.

Eskiköy, Yasin : "Dünya'da 30 Milyon Modern Köle Var", Sabah Gazetesi, 18.10.2013.

Göze, Ayferi: Siyasal Düşünceler ve Yönetimler, İstanbul, Beta Basım Yayım, 1986.

Kırım, Arman: Türkiye Nasıl Zenginleşir? İstanbul, Remzi Kitabevi, 2008.

Kongar, Emre: Toplumsal Değişme Kuramları ve Türkiye Gerçeği, İstanbul, Remzi Kitabevi, 1985.

Politzer, Georges: Felsefenin Temel İlkeleri, 5. bs., Çev. Erol Esençay, İzmir, İlya İzmir Yayınevi, 2010.

Nursi, Bediüzzaman Said: Muhakemat, İstanbul, Sözler Yayınevi, 1977.

Nursi, Bediüzzaman Said: Sözler, Zehra Yayıncılık, İstanbul, 2013.

Omay, Umut: Emeğin Kültür ve Manipülasyon Teorisi, İstanbul, Beta Basım, 2009.

Rand, Ayn: İnsan Hakları, Bencilliğin Erdemi, Çev. Nejdet Kandemir, İstane bul, Plato Film Yayınları, 2008. 
Sweezy, Paul: Feodalizmden Kapitalizme Geçiş, 3 bs. Çev. Müge Gürer- Set mih Sökmen, İstanbul Metis Yayınları, 1984.

Tokuroğlu, Belma, E. Abdullah: Uygarlık Tarihi, İmaj Kitabevi, Ankara, 2011.

Torun, Yıldırım: Demokrasi ve Cumhuriyet, Ankara, Orion Yayınevi, 2005.

Tufan, Tülay Erkan, H.: Kadastronun Ekonomik Kalkınmadaki Rolü, Ankara, 13. Türkiye Harita Bilimsel ve Teknik Kurultayı, TMMOB Harita ve Kadastro Mühendisleri Odas1, 18-22 Nisan 2011.

Uysal, Ömer Faruk: http://omerfarukuysal.8m.com/kure001.htm 12.12.2014.

Veysal, Çetin: Savaşın Felsefesi, 2. bs. İstanbul, Etik yayınları, 2010. 